\title{
PENENTUAN TOTAL FENOLIK DAN UJI AKTIVITAS ANTIOKSIDAN PADA BIJI DAN KULIT BUAH PINANG YAKI (Areca vestiaria Giseke)
}

\author{
Jefriyanto Ismail ${ }^{1)}$, Max R.J. Runtuwene ${ }^{1)}$, Feti Fatimah ${ }^{1)}$ \\ 1) Program Studi Kimia, Fakultas Matematika dan Ilmu Pengetahuan Alam, \\ Universitas Sam Ratulangi, Manado \\ Jl. Kampus Unsrat Manado, 95115 \\ e-mail : Jh3fry_j3j3@yahoo.co.id ; max_runtuwene@yahoo.com ; Fetysanusi@yahoo.com
}

\begin{abstract}
ABSTRAK
Telah dilakukan penelitian untuk menentukan kandungan total fenolik dan menguji aktivitas antioksidan pada biji dan kulit buah pinang yaki. Ekstrak biji dan kulit buah pinang yaki diperoleh dengan maserasi tanpa sokletasi dan maserasi setelah sokletasi. Total fenolik diuji dengan metode Folin-Ciocalteu dan uji aktivitas antioksidan dengan metode DPPH. Hasil penelitian yang diperoleh, kandungan total fenolik Maserasi Biji Setelah Sokletasi, Maserasi Kulit Setelah Sokletasi berturut-turut memiliki nilai sebagai berikut : $85,92 \mathrm{mg} / \mathrm{kg}, 3,16 \mathrm{mg} / \mathrm{kg}$. sedangkan aktivitas antioksidan Maserasi Biji Setelah Sokletasi, Maserasi Kulit Setelah Sokletasi berturut-turut memiliki nilai sebagai berikut : $88,16 \%, 54,11 \%$.
\end{abstract}

Kata kunci : Antioksidan, Areca vestiaria Giseke, DPPH, Total Fenolik

\section{TOTAL PHENOLIC COMPOUNDS AND ANTIOXIDANT ACTIVITY OF THE SEED AND SKIN OF PINANG YAKI (Areca vestiaria Giseke) FRUITS}

\begin{abstract}
This research has been conducted to measure the total phenolic compounds and the antioxidant activity of the seed and skin of pinang yaki fruits. The samples of the seed and skin were prepared separetely by maceration and soxhlet extraction followed by maceration. FolinCiocalteu method was used to measure the total phenolic compounds of while DPPH $(1,1$ diphenyl-2-pikrilhidrazil) method was used to measure the antioxidant activity. The total phenolic compounds of the seed by soxhlet extraction followed by maceration, skin by soxhlet extraction followed by maceration and were $85,92 \mathrm{mg} / \mathrm{kg}, 3,16 \mathrm{mg} / \mathrm{kg}$ respectively. The antioxidant activity of the seed by soxhlet extraction followed by maceration, skin by soxhlet extraction followed by maceration and were $88,16 \%, 54,11 \%$ respectively.
\end{abstract}

Keywords : Antioksidant, Areca vestiaria Giseke, DPPH, Total Phenolic Compounds

\section{PENDAHULUAN}

Banyak produk makanan dan minuman yang berlabel antioksidan beredar dipasaran. Produk-produk tersebut dijual dengan harga yang cukup mahal. Banyak orang tidak menyadari bahwa di alam terdapat antioksidan yang melimpah. Sarastani et al. (2002) menyatakan, banyak bahan pangan yang dapat menjadi sumber antioksidan alami, misalnya rempah-rempah, teh, coklat, dedaunan, biji-bijian, sayur-sayuran, enzim dan protein. Sumber antioksidan alami didominasi oleh tumbuhan dan umumnya mengandung senyawa fenolik yang tersebar di seluruh bagian tumbuhan.

Pinang yaki merupakan salah satu tanaman hias. Di Sulawesi Utara tanaman tersebut selain tumbuh di kawasan Taman Nasional Bogani Nani Wartabone, pinang yaki (Areca vestiaria Giseke) juga tumbuh di cagar alam gunung Ambang kabupaten Bolaang Mongondow, cagar alam gunung Tangkoko dua saudara, di lereng gunung Soputan dan gunung Mahawu kabupaten Minahasa. Tanaman pinang yaki tersebut oleh masyarakat di Bolaang Mongondow yang tinggal dikawasan Taman Nasional Bogani Nani Wartabone digunakan sebagai 
obat untuk penyakit diabetes dan juga dipakai sebagai obat kontrasepsi (Simbala, 2007).

Buah pinang yaki mengandung senyawa-senyawa metabolit sekunder seperti alkaloid, flavonoid, triterpenoid, steroid, dan tanin yang memiliki efek sebagai antifertilisasi (Simbala, 2007). Tujuan penelitia adalah menentukan total fenolik dan menguji aktivitas penangkal radikal bebas ekstrak etanol pada biji dan kulit buah pinang yaki (Areca vestiaria Giseke).

\section{METODOLOGI PENELITIAN}

\section{Bahan dan Alat}

Bahan-bahan yang digunakan adalah biji dan kulit buah pinang yaki yang diambil dari gunung Mahawu (Tomohon, Sulawesi Utara), petroleum eter, etanol, akuades, natrium karbonat $\left(\mathrm{Na}_{2} \mathrm{CO}_{3}\right)$, reagen FolinCiocalteu, DPPH $(1,1$ diphenyl-2pikrilhidrazil). Alat-alat yang digunakan adalah alat-alat gelas laboratorium, pengaduk magnetik, oven, vortex, water bath, timbangan analitik, evaporator yang dimodifikasi, spektrofotometer UV-Vis Milton Roy 501.

\section{Preparasi Sampel}

Buah pinang yaki dibersihkan dari pengotor lalu dipisahkan antara biji dan kulit buah. Untuk biji pinang yaki ditumbuk sampai kecil-kecil kemudian dikeringkan 4 hari kemudian dihancurkan (diblender). Setelah halus, biji pinang yaki dikeringkan 3 hari lalu diayak menggunakan ayakan ukuran 65 mesh, sehingga menghasilkan serbuk biji pinang yaki. Untuk kulit buah pinang yaki dipotong kecil-kecil lalu dikeringkan 5 hari kemudian dihancurkan (diblender). Kemudian dikeringkan selama 2 hari lalu diayak menggunakan ayakan ukuran 65 mesh, sehingga menghasilkan serbuk kulit buah pinang yaki.

\section{Ekstraksi Sampel Maserasi Tanpa Sokletasi}

Serbuk biji dan kulit buah pinang yaki masing-masing dimaserasi dengan etanol 96\% selama 24 jam. Sampel disaring dan filtrat yang diperoleh ditampung sedangkan residu diekstraksi lagi. Larutan dievaporasi kemudian dikeringkan dalam oven dengan suhu $40^{\circ} \mathrm{C}$ sampai kering hingga diperoleh ekstrak pekat biji dan kulit buah pinang yaki.

\section{Maserasi Setelah Sokletasi}

Serbuk biji dan kulit buah pinang yaki masing-masing disokletasi dengan pelarut petroleum eter selama 2 jam. Residu diambil dan dikering-anginkan sampai kering lalu dimaserasi dengan etanol 96\% selama 24 jam. Sampel disaring dan filtrat yang diperoleh ditampung sedangkan residu diekstraksi lagi. Larutan tersebut dievaporasi kemudian dikeringkan dalam oven pada suhu $40^{\circ} \mathrm{C}$ hingga diperoleh ekstrak pekat biji dan kulit buah pinang yaki.

\section{Penentuan Kandungan Total Fenolik}

Penentuan kandungan total fenolik menurut (Singleton and Rossi, 1965) yang telah dimodifikasi. Masing-masing sebanyak $0,1 \mathrm{~mL}$ ekstrak biji dan kulit buah pinang yaki $200 \mu \mathrm{g} / \mathrm{mL}$ dimasukkan ke dalam tabung reaksi, ditambahkan 0,1 Larutan FolinCiocalteu reagen 50\% kemudian divortex selama 1 menit. Larutan tersebut ditambahkan $2 \mathrm{~mL}$ Larutan natrium karbonat $\left(\mathrm{Na}_{2} \mathrm{CO}_{3}\right) 2 \%$. Campuran ini disimpan dalam ruangan gelap selama 30 menit. Absorbansi larutan ekstrak dibaca pada panjang gelombang $750 \mathrm{~nm}$ dengan spektrofotometer UV-Vis. Hasilnya dinyatakan sebagai $\mathrm{mg}$ asam galat/Kg ekstrak.

\section{Penentuan Aktivitas Penangkap Radikal Bebas DPPH}

Penentuan aktivitas penangkapan radikal bebas DPPH menurut (Bondet, et al. 1997) yang telah dimodifikasi. $0,5 \mathrm{~mL}$ ekstrak biji dan kulit buah pinang yaki 200 $\mu \mathrm{g} / \mathrm{mL}$ masing-masing dituangkan kedalam tabung reaksi dan ditambahkan $2 \mathrm{~mL}$ larutan DPPH $0,2 \mathrm{mM}$. Larutan blanko dibuat dengan cara larutan DPPH 0,2 mM dipipet sebanyak $2 \mathrm{ml}$ kemudian dimasukkan kedalam tabung reaksi dan ditambahkan dengan etanol $0,5 \mathrm{~mL}$.

Absorbansi DPPH diukur dengan spektrofotometer UV-Vis pada panjang gelombang $517 \mathrm{~nm}$, setelah diinkubasi dalam ruang tanpa cahaya selama 30 menit. Kemampuan antioksidan diukur sebagai penurunan serapan larutan DPPH akibat adanya penambahan sampel. Nilai serapan larutan DPPH sebelum dan sesudah 
penambahan ekstrak tersebut dihitung sebagai persen aktivitas antioksidan dengan rumus sebagai berikut:

$$
\begin{aligned}
& \% \text { Aktivitas antioksidan } \\
= & \left(1-\frac{\text { A sampel }}{\text { A kontrol }}\right) \times 100 \%
\end{aligned}
$$

Keterangan:

A kontrol = Absorbansi tidak mengandung sampel A sampel $=$ Absorbansi sampel

\section{HASIL DAN PEMBAHASAN}

\section{Rendemen}

Rendemen yang diperoleh dapat dilihat pada Tabel 1.

Tabel 1. Rendemen ekstrak biji dan kulit buah pinang yaki

\begin{tabular}{|l|l|c|}
\hline No & \multicolumn{1}{|c|}{ Metode Ekstraksi } & $\begin{array}{c}\text { Rendemen } \\
(\mathbf{\%})\end{array}$ \\
\hline 1 & $\begin{array}{l}\text { Maserasi Biji Setelah } \\
\text { Sokletasi (MBSS) }\end{array}$ & 22,39 \\
\hline 2 & $\begin{array}{l}\text { Maserasi Kulit Setelah } \\
\text { Sokletasi (MKSS) }\end{array}$ & 7,61 \\
\hline
\end{tabular}

Ket: Maserasi menggunakan pelarut Etanol 96\% ; Sokletasi menggunakan pelarut Petroleum eter

Kulit buah memiliki rendemen paling sedikit. Hal tersebut disebabkan kurangnya komponen polar yang terdapat dalam kulit buah pinang yaki. Kelarutan komponenkomponen tersebut sacara kualitatif dapat dilihat pada Tabel 2. Selain dipengaruhi oleh komponen-komponen dalam sampel, ukuran sampel juga merupakan salah satu faktor yang mempengaruhi hasil rendemen. Menurut Sembiring et al. (2006), semakin halus bahan yang digunakan semakin tinggi rendemen yang dihasilkan. Perbesaran luasan permukaan bertujuan untuk mempercepat pelarutan, mempercepat reaksi kimia, dan mempertinggi kemampuan penyerapan (Bernasconi et al. dalam Muhiedin, 2008). Data hasil warna ekstrak dapat dilihat pada Tabel 2.

Tabel 2. Warna ekstrak biji dan kulit buah pinang yaki

\begin{tabular}{|c|c|c|c|}
\hline No & $\begin{array}{c}\text { Nama } \\
\text { Sampel }\end{array}$ & $\begin{array}{c}\text { Sokletasi } \\
\text { dengan } \\
\text { P.E. }\end{array}$ & $\begin{array}{c}\text { Maserasi } \\
\text { dengan } \\
\text { Etanol }\end{array}$ \\
\hline 1 & $\begin{array}{c}\text { Biji buah } \\
\text { pinang yaki }\end{array}$ & Kuning & $\begin{array}{c}\text { Coklat } \\
\text { kemerahan }\end{array}$ \\
\hline 2 & $\begin{array}{c}\text { Kulit buah } \\
\text { pinang yaki }\end{array}$ & Merah & $\begin{array}{c}\text { Coklat } \\
\text { kekuningan }\end{array}$ \\
\hline
\end{tabular}

Data Tabel 2 menunjukkan adanya perbedaan warna ekstrak pada biji dan kulit buah pinang yaki sesuai dengan komponen sampel yang larut dalam pelarut. Penggunaan pelarut yang berbeda tingkat kepolaran mempengaruhi jenis senyawa yang terekstrak (Soeksmanto et al., 2007). Petroleum eter adalah pelarut yang digunakan untuk mengekstrak komponen yang terdapat dalam biji dan kulit buah pinang yaki. Pelarut tersebut merupakan pelarut non polar dapat digunakan untuk memudahkan proses ekstraksi komponen non polar (Widyawati et al., 2010). Komponen yang diduga berkontribusi terhadap ekstrak non polar adalah klorofil, minyak atsiri dan lemak (Suryanto et al., 2008).

Pada biji pinang yaki setelah disokletasi terlihat adanya perubahan warna pelarut dari bening menjadi kuning. Hal tersebut menunjukkan adanya komponen non polar yang terekstrak oleh pelarut. Lisa (2011) menyatakan, salah satu komponen yang dapat terekstrak oleh petroleum eter pada biji pinang yaki adalah metil heksadekanoat. Senyawa tersebut memiliki nama lain asam palmitat. Menurut Laksmono dan Wuryaningsih (2003), pembawa warna kuning pada minyak kemiri adalah asam stearat dan asam palmitat.

Pada kulit buah pinang yaki setelah disokletasi terlihat adanya perubahan warna pelarut dari bening menjadi merah. Hal tersebut menunjukkan adanya komponen non polar yang terekstrak oleh pelarut dan diduga sebagai senyawa karotenoid. Menurut Susilowati (2008), karotenoid biasanya terdapat pada buah-buahan yang berwarna merah. Kumalaningsih dalam Susilowati (2008) mengatakan, karotenoid larut dalam lemak, minyak makan pada suhu kamar dan pelarut organik, tetapi tidak larut dalam air.

\section{Kandungan Total Fenol Ekstrak Biji dan Kulit Buah Pinang Yaki}

Data hasil kandungan total fenol dapat dilihat pada Gambar 1. 


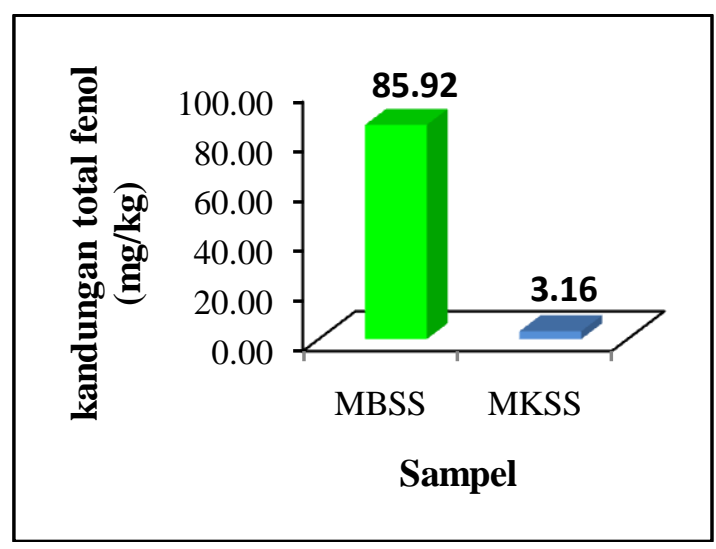

Gambar 1. Diagram kandungan total fenol pada biji dan kulit buah pinang yaki

Berdasarkan Gambar 1 dapat dilihat bahwa kandungan total fenol tertinggi terdapat pada biji. Hal tersebut sebanding dengan aktivitas antioksidannya yang dapat dilihat pada Gambar 2. Kulit buah hanya memberikan hasil yang minim. Hasil yang diperoleh berbanding terbalik dengan aktivitas antioksidannya. Hal tersebut diduga disebabkan kulit buah mengandung senyawa yang berpotensi sebagai antioksidan selain senyawa fenolik. Salah satu senyawa yang mempunyai aktivitas antioksidan selain senyawa fenolik adalah senyawa karotenoid (Ndhlala et al., 2010). Perbandingan kandungan total fenol dan aktivitas antioksidan dapat dilihat pada Tabel 1 .

Tabel 1. Perbandingan kandungan total fenol dan aktivitas antioksidan

\begin{tabular}{|c|c|c|c|}
\hline $\begin{array}{l}\mathbf{N} \\
\mathbf{o}\end{array}$ & $\begin{array}{c}\text { Jenis } \\
\text { sampel }\end{array}$ & $\begin{array}{c}\text { Kandungan } \\
\text { Total Fenol } \\
(\mathbf{m g} / \mathbf{k g})\end{array}$ & $\begin{array}{c}\text { Aktivitas } \\
\text { antioksidan } \\
(\boldsymbol{\%})\end{array}$ \\
\hline 1 & MBSS & 85,92 & 88,16 \\
\hline 2 & MKSS & 3,16 & 54,11 \\
\hline
\end{tabular}

Wei-Min et al. (2009) mengatakan, flavonoid adalah komponen utama total fenolik dari bunga, sekam dan biji pinang (Areca catechu L). Dalam studi Zhang et al. (2010), senyawa fenilpropanoid baru dan 10 senyawa fenolik yang dikenal diisolasi dari ekstrak etil asetat buah pinang (Areca catechu) kecuali katekin yang diisolasi dari genus Areca. Semua senyawa tersebut menunjukkan tingkat aktivitas antioksidan.

Pada saat direaksikan antara reagen Folin-Ciocalteu dengan senyawa fenolik akan terjadi perubahan warna dari kuning menjadi biru. Intensitas warna biru ditentukan dengan banyaknya kandungan fenol dalam larutan sampel. Semakin besar konsentrasi senyawa fenolik dalam sampel semakin pekat warna biru yang terlihat. Menurut Singleton dan Rossi (1965), Warna biru yang teramati berbanding lurus dengan konsentrasi ion fenolat yang terbentuk, semakin besar konsentrasi senyawa fenolik maka semakin banyak ion fenolat yang terbentuk sehingga warna biru yang dihasilkan semakin pekat. Fenolat hanya terdapat pada larutan basa, tetapi pereaksi Folin-Ciocalteu dan produknya tidak stabil pada kondisi basa. Nely (2007) mangatakan, penambahan $\mathrm{Na}_{2} \mathrm{CO}_{3}$ pada uji fenolik bertujuan untuk membentuk suasana basa agar terjadi reaksi reduksi Folin-Ciocalteu oleh gugus hidroksil dari fenolik di dalam sampel.

\section{Aktivitas Antioksidan Ekstrak Biji dan Kulit Buah Pinang Yaki}

Hasil presentase aktivitas penangkal radikal bebas dapat dilihat pada Gambar 3 .

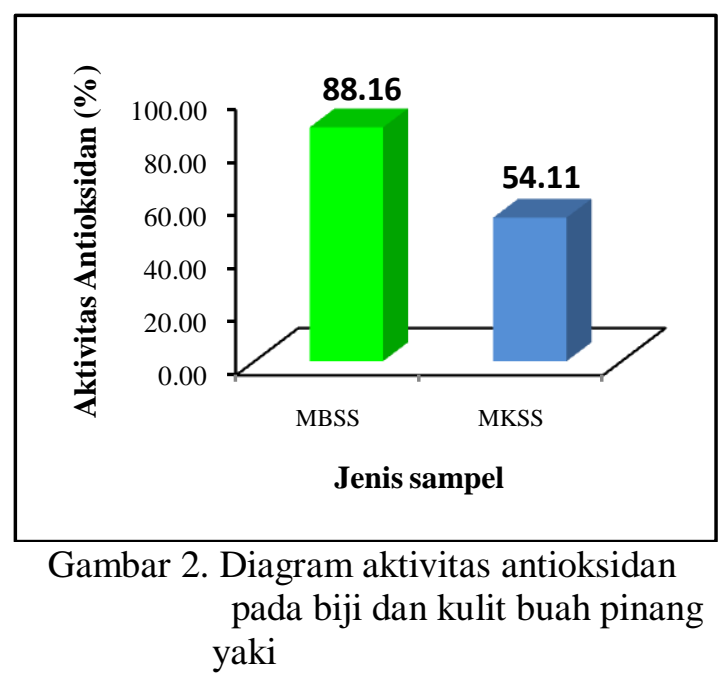

Berdasarkan Gambar 2 dapat dilihat bahwa biji buah pinang yaki memiliki aktivitas antioksidan yang lebih tinggi. Hasil ini sesuai dengan biji pinang (Areca catechu) juga dilaporkan memiliki aktivitas antioksidan tertinggi dibandingkan sekam dan bunga (Wei-Min et al., 2009).

\section{KESIMPULAN DAN SARAN}

\section{Kesimpulan}

Ekstrak biji dan kulit buah pinang yaki memiliki kandungan total fenol 82,92 $\mathrm{mg} / \mathrm{kg}$ dan $3,16 \mathrm{mg} / \mathrm{kg}$ dan memiliki aktivitas antioksidan $88,16 \%$ dan $54,11 \%$. 


\section{Saran}

Perlu diidentifikasi senyawa bukan fenolik yang memberikan kontribusi terhadap aktivitas antioksidan pada biji dan kulit buah pinang yaki.

\section{DAFTAR PUSTAKA}

Bondet,V., W.Brand-Williams and C.Berset. 1997. Kinetics and Mechanisms of Antioxidant Activity using the DPPH• Free Radical Method.Lebensm-Wis.u.Technol 30: 609-615.

Laksono, J.A. dan S.R.Wuryaningsih. 2003. adsorpsi warna pada minyak kemiri hasil ekstraksi. [Kedeputian Ilmu Pengetahuan Teknik]. LIPI. Bandung.

Muhiedin,F. 2008. Efisiensi Proses Ekstraksi Oleoresin Lada Hitam dengan Metode Ekstraksi Multi Tahap [skripsi]. Brawijaya. Malang.

Ndhlala,A.R., M.Moyo and J.V.Staden. 2010. Natural Antioxidants : Fascinating or Mythical Biomolecules ?. Molecules 15: 6905-6930.

Nely,F. 2007. Aktivitas Antioksidan Rempah Pasar dan Bubuk Rempah Pabrik dengan Metode Polifenol dan Uji AOM (Active Oxygen Method) [skripsi]. Institud Pertanian Bogor, Bogor.

Sarastani,D., T.Suwarna, Soekarto, R.Tien, R.Muchtadi, D.Fardiaz dan A.Apriyanto. 2002. Aktivitas Antioksidan Ekstrak dan Fraksi Ekstrak Biji Atung. Teknologi dan Industri Pangan.13: 149-156.

Sembiring,B.B., Ma'mun dan E.I.Ginting. 2006. Pengaruh Kehalusan Bahan dan Lama Ekstraksi Terhadap Mutu Ekstrak Temulawak (Curcuma xanthorriza Roxb). Bul. Littro 17: $53-58$.

Simbala,H.E.I. 2007. Keanekaragaman Floristik dan Pemanfaatan Sebagai Tumbuhan Obat di Kawasan Konservasi II Taman Nasional Bogani Nani Wartabone (Kabupaten Bolaang Mongondow, Sulawesi Utara) [Disertasi]. Institut Pertanian Bogor, Bogor.
Singleton,V.L. and J.A Rossi. 1965. Colorimetry of Total Phenolic with Phosphomolybdic-Phosphotungstic Acid Reagent. American Journal Enology and Viticulture. 16: 147.

Soeksmanto,A., Y.Hapsari dan P.Simanjuntak. 2007. Kandungan Antioksidan pada Beberapa Bagian Tanaman Mahkota Dewa, Phaleria macrocarpa (Scheff) Boerl. (Thymelaceae). Biodiversita. 8: 92-95.

Suryanto,E., F.Wehantou, S.Raharjo. 2008. Aktivitas Penstabilan Senyawa Oksigen Reaktif dari Beberapa Herbal. Jurnal obat bahan alam. 7: 62-68.

Susilowati. 2008. Isolasi dan Identifikasi Senyawa Karotenoid dari Cabai Merah (Capsicum annuum Linn.) [skripsi]. Universitas Islam Negeri Malang, Malang.

Wei-Min,Z., L.Bin, H.Lin and Z.Hai-De. 2009. Antioxidant activities of extracts from areca (Areca catectu L.) flower, husk and seed. African Journal of Biotechnology 8: 3887-3892.

Widyawati,P.S., C.H.Wijaya, P.S.Harjosworo dan D.Sajuthi. 2010. Pengaruh Ekstraksi dan Fraksinasi Terhadap Kemampuan Menangkap Radikal Bebas DPPH (1,1-difenil-2Pikrilhidrazil) Ekstrak dan Fraksi Daun Beluntas (Pluchea indica Less) [Seminar rekayasa kimia dan proses]. Diponegoro, Semarang. 